\title{
The American Academy of
} Audiology Honors Committee: A Mechanism to Acknowledge

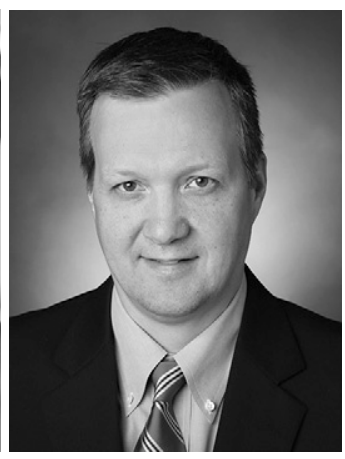
Those in Audiology Who Have Gone Above and Beyond in Their Contribution to the Profession

$\mathrm{E}$ very year at the annual convention, the American Academy of Audiology takes the time to honor a handful of leaders for their significant contributions to the areas of hearing and balance. The awards are presented during the Academy's Honors and Awards Banquet and are hosted by the Chair of the Academy Honors Committee.

The award winners are nominated by the Academy membership. Any member may nominate someone for the various awards. The mission is to award those who have contributed significantly and selflessly to improve patient care through philanthropy, educating the next generation, research, industry, or clinic.

\section{The Awards}

The Academy Honors program offers nine different awards to address the various aspects of the profession. The Honors of the Academy award, a highly competitive honor, recognizes one audiologist and one non-audiologist who have demonstrated significant contributions to the profession through hearing and balance. This is considered one of the broader award categories that allows the opportunity to nominate many deserving individuals.

The remaining eight awards have a narrower scope.

The Jerger Career Award for Research in Audiology honors an individual who has significantly contributed to growing the body of research in auditory or vestibular sciences.

The Clinical Excellence in Audiology Award is a nod to those individuals who have provided a lifetime of clinical service and are master clinicians. This award is given to an audiologist whose dedication to clinical care has improved the quality of life for numerous individuals. This award also encompasses those who provide superior clinical education, public awareness, and innovation in service provision.

Marion Downs was the pioneer of research and clinical services for pediatric patients with hearing loss. Her dedication, hard work, and love of children inspired the Marion Downs Pediatric Audiology Award. This award recognizes an individual who has significantly contributed to pediatric audiology as a clinician, scientist, or educator.

The most highly nominated category award is the Early-Career Audiologist Award. This award serves to highlight and encourage audiologists who have been in the field for less than 10 years. The award is given to someone who, early in their career, has made significant contributions in the areas of clinical practice, teaching, advocacy, research, and overall exceptional service to the profession.

The Samuel F. Lybarger Industry Award is presented to an individual in industry who has made a significant contribution in the realm of research or engineering. The winner is not required to be an audiologist, but should be employed by a company in the hearing health-care field.

For our colleagues who work or reside out outside of the United States, the International Award for Hearing honors those who have made contributions to audiology in a clinical, academic, research, or professional capacity.

The Humanitarian Award is given to those who dedicate their work to individuals in need of services 
and who are disadvantaged by accessibility to services, economics, and geography. The award focuses on those who have provided significant voluntary and/or philanthropic contributions by providing hearing care services, developing education programs, or offering other service activities.

The Outstanding Educator Award focuses on an individual who has dedicated her or his efforts to the education of audiology students. The educator's focus may be clinical or academic, but he or she must be a full faculty member (not an adjunct faculty member).

\section{The Nomination Process}

The Honors Committee relies solely on nominations from Academy members; this is not an internal nomination process. As an Academy member, you have an opportunity to acknowledge a worthy colleague, co-worker, or mentor for any of the awards.

The nomination process is simple. The nominator submits a package, including a letter that attests to how the nominee meets (exceeds) the criteria of the award, along with the nominee's curriculum vitae or resume. Descriptions, policies, and information about nomination packets can be found on the Academy's website (https://www.audiology.org/about-us/academyinformation/academy-honors).

Once the applications are received, the Academy Honors Committee compiles the applications, scores each application, and votes. The committee is composed of Academy members from many different specialty areas in the field of audiology. If you would like to serve on the committee, fill out the volunteer form on the online Audiology Community.

The culmination of the process-the Academy Honors and Awards Banquet-is the best part. The banquet is held during the Academy's annual conference and is always well attended. During the banquet, the awardees share their accomplishments with family, friends, and colleagues. In 2020, the banquet will be held during the annual conference at the meeting venue in New Orleans, LA, on April 2, 2020.

\section{Nominate a Colleague}

Please take a moment to consider nominating someone for one of the nine available awards. Our profession has so many wonderful colleagues that deserve recognition for their research, clinical services, humanitarian efforts, and teaching. Listed below are the most recent honorees. An inclusive list of all past award winners appears on the Academy website.

The 2019 Academy Honorees are:

Angela Loavenbruck, EdD - Honors of the Academy

M. Patrick Feeney, PhD - Jerger Career Award for Research in Audiology

Debra Fried, MS - Humanitarian Award

Gail M. Whitelaw, PhD - Outstanding Educator Award

Erin G. Piker, AuD, PhD —Early-Career Audiologist Award

Alison M. Grimes, AuD - Marion Downs Pediatric Audiology Award

David T. Kemp, PhD, FRS - International Award for Hearing

More information can be found at: https://www. audiology.org/about-us/academy-information/academyhonors

Patricia Gaffney, AuD Chair, Academy Honors Committee

Devin L. McCaslin, PhD Deputy Editor, Journal of the American Academy of Audiology Academy Honors Committee Member 